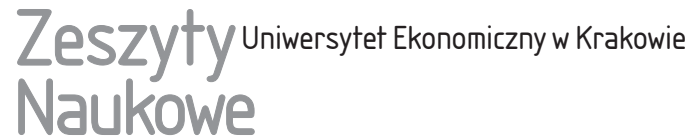

\author{
Jan Madej
}

\section{Koncepcja zarządzania aktami sądowymi w postaci cyfrowej"}

\section{Streszczenie}

W artykule przedstawiono nową koncepcję dobrej praktyki z zakresu IT wykorzystania systemu klasy document management system (DMS) w zarządzaniu aktami sądowymi w postaci cyfrowej. Koncepcja dobrej praktyki powstała podczas realizacji projektu „PWP Edukacja w dziedzinie zarządzania czasem i kosztami postępowań sądowych - case management” w ramach programu operacyjnego „Kapitał ludzki”. Projekt ten był jednym z elementów wspierających reformę polskiego wymiaru sprawiedliwości i miał na celu podniesienie efektywności procesu orzecznictwa sądów poprzez skrócenie jego czasu, zmniejszenie kosztów oraz podniesienie kwalifikacji pracowników sądownictwa. Zaprezentowano nowe rozwiązania zarządzania w sądach aktami w postaci cyfrowej oraz warunki i tło zaproponowanej praktyki, cele i korzyści wynikające z jej wdrożenia oraz podstawowe założenia, zakres i funkcje, które powinny być przez nią realizowane na różnych poziomach dojrzałości. Na zakończenie podano wnioski z wdrożenia dobrej praktyki.

Słowa kluczowe: system zarządzania dokumentami, system informacyjny, dobre praktyki informatyczne, wymiar sprawiedliwości, sądy, efektywność orzecznictwa.

Klasyfikacja JEL: M15, K00.

Jan Madej, Uniwersytet Ekonomiczny w Krakowie, Wydział Zarządzania, Katedra Informatyki, ul. Rakowicka 27, 31-510 Kraków, e-mail: madejj@uek.krakow.pl, ORCID: https://orcid.org/ 0000-0003-1398-1285.

* Artykuł powstał w wyniku prac nad projektem pt. „PWP Edukacja w dziedzinie zarządzania czasem i kosztami postępowań sądowych - case management”, nr projektu POKL.05.03.00-00-012/11. 


\section{Wprowadzenie}

Koncepcja dobrej praktyki z zakresu IT dotycząca zarządzania aktami sądowymi w postaci cyfrowej została opracowana w ramach pilotażu dobrego zarządzania jednostkami wymiaru sprawiedliwości podczas realizacji projektu „PWP Edukacja w dziedzinie zarządzania czasem i kosztami postępowań sądowych - case management” programu operacyjnego „Kapitał ludzki” (Badanie ewaluacyjne... 2015). Rezultatem projektu było opracowanie dobrych praktyk (nie tylko informatycznych) i ich wdrożenie w 60 sądach różnych szczebli. Autor artykułu był członkiem zespołu ekspertów zajmujących się opracowaniem koncepcji dobrych praktyk informatycznych. Warunki realizacji projektu oraz metodyka i etapy tworzenia praktyk z zakresu IT zostały szczegółowo przedstawione w artykule (Grabowski, Madej i Trąbka 2018). Należy zaznaczyć, że dużym problemem wdrożeniowym i ciekawym zagadnieniem badawczym było zaimplementowanie rozwiązań z obszaru biznesu w specyficznych organizacjach, jakimi są sądy. Już na początku prac okazało się, że różniące się od rynkowych regulacje prawne, formalna i nieformalna struktura zależności, szeroko rozumiana niezawisłość sędziowska oraz rozbieżne oczekiwania prezesów i dyrektorów sądów co do informatyzacji tych jednostek sprawiły, że powszechnie stosowane rozwiązania informatyczne, pomimo niekwestionowanych zalet, nie mogły być wdrożone bezpośrednio (por. Informatyzacja... 2016). Z tego powodu zespół badawczy postanowił wykorzystać metodę action research (AR), starając się zrozumieć sposób postrzegania sądów przez ich pracowników, aby istniejące problemy mogły być rozwiązywane zgodnie z ich oczekiwaniami ${ }^{1}$. Ostatecznie, po przeprowadzonych obserwacjach rozwiązań informatycznych stosowanych w sądach oraz po analizie potrzeb (i pomysłów na ich zaspokojenie) zgłaszanych przez pracowników sądów, powstały koncepcje dobrych praktyk z zakresu IT. Dodatkowo - ze względu na różne oczekiwania co do sposobu i stopnia ich wdrożenia - dobre praktyki uwzględniły także kilka poziomów ich realizacji, które nawiązywały bezpośrednio do koncepcji poziomów dojrzałości systemu (Paulk i in. 1993) i standardu COBIT (COBIT 4.1... 2010).

${ }^{1}$ Dzięki takiemu podejściu do prowadzonych badań metoda action research pozwala na odkrywanie teorii potrzebnej do rozwiązywania problemów praktycznych i umożliwia m.in. lepsze zrozumienie złożonego zjawiska oraz równoczesne rozwiązywanie problemów i zdobywanie wiedzy naukowej (Baskerville i Wood-Harper 1996, Baskerville 1999). Pomimo że action research wywodzi się z nauk społecznych, a niektórzy badacze krytykowali ją za brak rygoru naukowego i duże podobieństwo do konsultingu (Davison, Martinsons i Kock 2004), to obecnie wraz ze studium przypadku należy do podstawowych metod $\mathrm{w}$ interpretacyjnym paradygmacie metodologicznym w SI (Cole i Avison 2007). 
Celem artykułu jest zaprezentowanie koncepcji dobrej praktyki, która przedstawia możliwości zarządzania w sądach aktami w postaci cyfrowej, tj. stworzenie i wykorzystanie w tym celu systemu klasy DMS (system zarządzania dokumentami, document management system). Koncepcja systemu zarządzania dokumentami w postaci elektronicznej nie jest nowa i sięga lat 80. ubiegłego wieku, kiedy to powstawały pierwsze systemy zarządzania dokumentami elektronicznymi (electronic document management system) zdobywające, wraz z rozwojem technologii informatycznych, coraz większą popularność (Green 1993, Sutton 1996). Obecnie systemy te w wielu firmach i organizacjach są standardem obok innych systemów wspomagających zarządzanie (Wachnik 2016, Keathley 2014, Laudon i Laudon 2016), a na rynku można znaleźć liczne rozwiązania oferowane dla różnej klasy i wielkości przedsiębiorstw (The Best... 2018). Ponadto systemy tej klasy zaczynają być wykorzystywane także w polskich urzędach (np. system Elektroniczne Zarządzanie Dokumentacją - EZD, http://ezd.gov.pl/).

\section{Warunki opracowania dobrej praktyki}

Gwałtowny rozwój technologii informatycznej oraz jej cechy, do których zalicza się m.in. szybkość i łatwość przetwarzania, gromadzenia, wyszukiwania i przesyłania danych, znalazły zastosowanie w wielu obszarach działalności ludzkiej, pozwalając na osiągnięcie licznych korzyści, takich jak np. przyśpieszenie i uproszczenie procesów informacyjnych czy zwiększenie dostępności informacji. Osiągnięcie tych korzyści było jednak możliwe tylko dzięki temu, że gromadzone i przetwarzane w systemach informatycznych dane mają postać cyfrową, a rozwijające się technologie sieciowe pozwalają na ich udostępnianie i przesyłanie.

Korzystanie z cyfrowych danych znalazło zastosowanie również w wymiarze sprawiedliwości i sądownictwie (Modernizacja procesów... 2011):

- udostępniono zasoby Krajowego Rejestru Sądowego i pozwolono na wyszukiwanie podmiotów, składanie wniosków o rejestrację, wydanie odpisów, zaświadczeń, informacji i kopii dokumentów,

- udostępniono informacje z Monitora Sądowego i Gospodarczego,

- opracowano system przekazywania informacji z Krajowego Rejestru Karnego do Krajowego Rejestru Sądowego,

- umożliwiono wgląd do ksiąg wieczystych; dzięki zastąpieniu rejestrów papierowych elektronicznymi obywatele otrzymali wgląd do ksiąg wieczystych bez konieczności wizyty w sądzie,

- wprowadzono usługę elektronicznego postępowania upominawczego (e-sąd), jako odrębnego postępowania, mającego charakter wezwania do zapłaty w sprawach niewymagających przeprowadzenia postępowania dowodowego, 
- opracowano system e-protokołu pozwalającego na rejestrację rozpraw,

- opracowano portale publikacji orzeczeń sądów powszechnych (Portale Orzeczeń), które ułatwiają uprawnionym podmiotom i przyspieszają dostęp do informacji w sprawach toczących się przed sądami oraz udostępniają informacje na temat wydawanych wyroków.

Ponadto w najbliższych latach - według Programu zintegrowanej informatyzacji państwa (2013) - planowane jest:

- opracowanie elektronicznego narzędzia wspomagającego pracę sądów, które umożliwi w postępowaniu cywilnym składanie pism procesowych w postaci elektronicznej oraz dostarczanie uczestnikom postępowań i pełnomocnikom elektronicznych pism i orzeczeń w toku postępowania;

- wprowadzenie nowoczesnej biurowości sądowej opartej na nowym, jednolitym dla całego kraju systemie repozytoryjno-biurowym, systemie elektronicznego obiegu dokumentów oraz elektronicznym archiwum akt sądowych;

- wprowadzenie informatyzacji rozpraw sądowych polegającej na ich rejestracji audio-wideo w sprawach cywilnych, wykroczeniowych oraz na dokonywaniu czynności procesowych (np. przesłuchiwanie świadków i biegłych) na odległość przy użyciu systemów wideokonferencji, co wyeliminuje konieczność osobistego stawiennictwa w sądzie;

- umożliwienie dostępu do informacji w sprawach toczących się przed sądami poprzez portal informacyjny. Dostęp taki będzie możliwy dzięki dedykowanemu systemowi, który pozwoli na identyfikację stron i ich pełnomocników oraz na wgląd do dokumentów znajdujących się w aktach elektronicznych sprawy. Pozwoli to obywatelom na zapoznanie się z aktami sądowymi oraz nagraniami rozpraw bez osobistej obecności w sądzie;

- stworzenie ogólnopolskiej bazy orzeczeń wydawanych przez sądy powszechne wraz z zaawansowaną wyszukiwarką, co umożliwi zapoznanie się z orzeczeniami sądowymi.

W kontekście przemian, które zaszły w polskim sądownictwie, oraz planowanych dalszych zmian, a także obserwacji, jak dzięki technologii informatycznej zmieniło się funkcjonowanie światowej gospodarki, zaproponowana została dobra praktyka „Zarządzanie aktami sądowymi w postaci cyfrowej”. Na wstępie należy jednak zaznaczyć, że w praktyce tej nie chodzi tylko o zwykłe przeniesienie akt papierowych do postaci cyfrowej, ale o opracowanie w pełni funkcjonalnego systemu zarządzania dokumentami. System DMS to narzędzie informatyczne, które pozwala na gromadzenie, przetwarzanie i udostępnianie różnych form dokumentów powstających w organizacji i przekazywanych do niej. Pojęcie dokumentu odnosi się tutaj zarówno do dokumentów papierowych, jak i dowolnych plików komputerowych (tekstowych, graficznych, dźwiękowych, wideo, plików wykonywalnych, tabel baz danych, danych z arkuszy kalkulacyjnych itd.), które ze 
względu na swoją zawartość muszą być przechowywane i udostępniane w organizacji (por. Stajda 2013). Przykładowy schemat funkcjonowania systemu DMS przedstawiony został na rys. 1 .

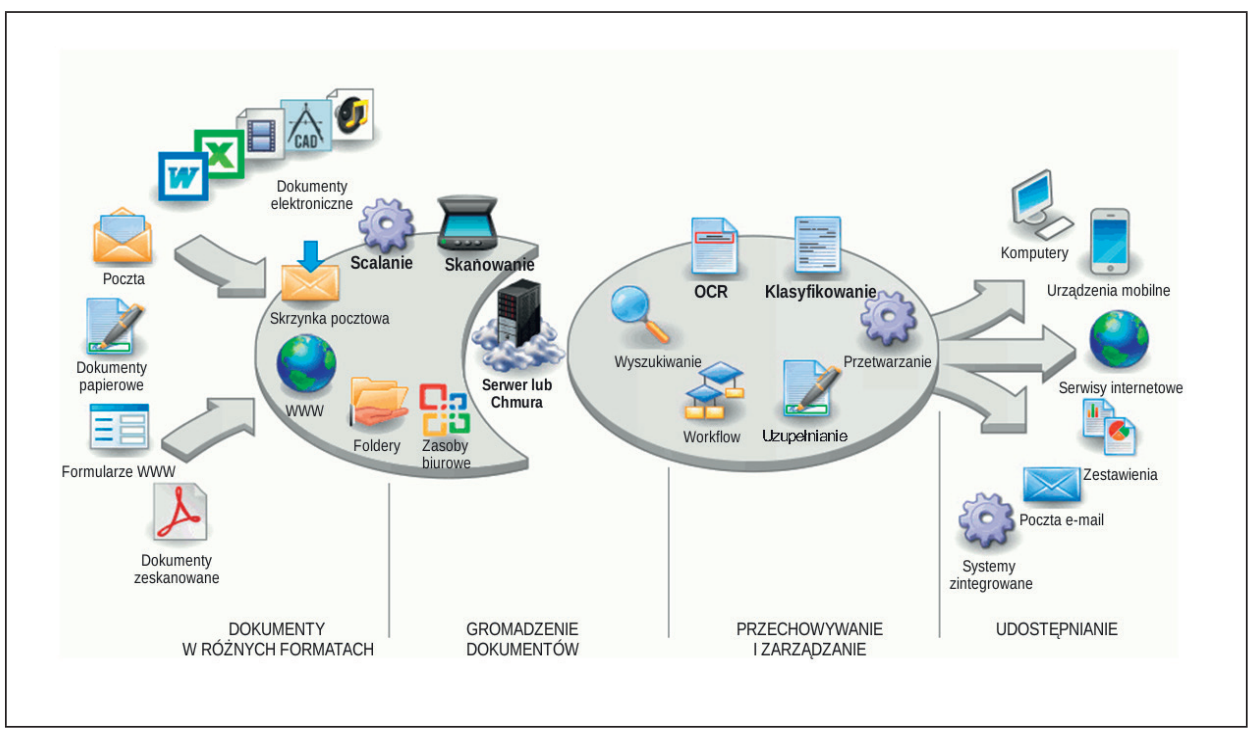

Rys. 1. Schemat systemu DMS

Źródło: opracowanie własne na podstawie www.bil-lander.com (data dostępu: 22.12.2016).

Do podstawowych funkcji systemu DMS należy (por. Green 1993, Azad 2008, Keathley 2014):

- dodawanie do systemu dokumentów elektronicznych w różnych formatach (np. tekst, zdjęcia, nagrania dźwiękowe, nagrania wideo) i z różnych źródeł,

- dodawanie do systemu dokumentów papierowych, które po odpowiednim przetworzeniu (digitalizacji) przyjmują postać dokumentów elektronicznych,

- gromadzenie wszystkich dokumentów dodanych do systemu,

- klasyfikowanie, porządkowanie, oznakowanie i opisywanie (komentowanie, tworzenie metryk) na poziomie dokumentów i ich zawartości,

- zarządzanie dokumentami (m.in. przetwarzanie, kontrolowanie wersji, synchronizowanie, powiadamianie o zmianach, sterowanie obiegiem dokumentów, archiwizowanie),

- zaawansowane udostępnianie dokumentów.

Rozwój systemów DMS jest odpowiedzią na istniejącą już od wielu lat tendencję do gromadzenia, przetwarzania i udostępniania przez przedsiębiorstwa rynkowe zasobów wyłącznie w postaci cyfrowej. Przedsiębiorstwa, które wdrożyły ideę „firmy bez papierów”, uzyskały dzięki temu duże oszczędności finansowe, przy 
jednoczesnej poprawie jakości procesów wewnętrznych i zewnętrznych. Coraz większa jest też dostępność oprogramowania przeznaczonego do zarządzania tego rodzaju dokumentami (Document Management... 2016, The Best... 2018).

Funkcjonalnie akta sądowe odgrywają rolę zbliżoną do dokumentacji gromadzonej w przedsiębiorstwach i ich digitalizacja pozwoliłaby na osiągnięcie podobnych korzyści, tym bardziej że istnieją techniczne możliwości przeprowadzenia takiej operacji, a na same akta sądowe coraz częściej składają się takie dokumenty, które:

- są już w postaci cyfrowej - m.in. filmy (np. nagrania z monitoringu), nagrania dźwięków, pliki i programy komputerowe, zawartość pamięci telefonów komórkowych,

- były w postaci cyfrowej, ale musiały zostać przeniesione na papier - m.in. zdjęcia, strony internetowe, e-maile, wiadomości SMS, logi systemowe, wykazy połączeń telefonicznych, wyciągi bankowe, faktury itd.

Uwzględniając wszystkie wewnętrzne dokumenty sądowe, które od początku są tworzone w postaci elektronicznej (np. zawartość systemu biurowości sądowej, nagrania e-protokołów, orzeczenia), dążenie do przetworzenia pozostałych dokumentów papierowych do postaci elektronicznej i przechowywanie ich w jednym informatycznym systemie zarządzania aktami wydaje się niezbędne i nieuniknione.

\section{Cele dobrej praktyki i korzyści wynikające z jej wdrożenia}

Głównym celem dobrej praktyki jest opracowanie i wdrożenie systemu informatycznego klasy DMS służącego do zarządzania cyfrowymi aktami sądowymi. Odbiorcami praktyki są przede wszystkim sędziowie orzekający. Jednak wraz z rozwojem systemu korzystać z niego będą mogły także strony postępowania. We wdrożenie praktyki zaangażowane będą niemal wyłącznie służby informatyczne sądu. Osiągnięcie celu głównego wymaga realizacji celów cząstkowych, do których należy m.in.:

- opracowanie systemu skanowania akt sądowych i rozpoznawania zawartych w nich treści z wykorzystaniem technologii optical character recognition (OCR),

- opracowanie rozwiązań pozwalających na przyjmowanie do akt sądowych dokumentów elektronicznych (także zewnętrznych) z zachowaniem ich autentyczności, wiarygodności i niezaprzeczalności,

- przyjmowanie do akt sądowych dokumentów w postaci elektronicznej (wewnętrznych i zewnętrznych),

- opracowanie reguł przechowywania i udostępniania akt w postaci elektronicznej,

- opracowanie mechanizmów gwarantujących bezpieczeństwo przechowywanych i udostępnianych akt. 
Wdrożenie systemu zarządzania dokumentami jest procesem wieloetapowym i wykorzystującym najnowsze technologie informatyczne. W sądach w tym obszarze największym wyzwaniem są akta sądowe przechowywane w postaci papierowej. Mając świadomość korzyści wynikających z ich transformacji do postaci cyfrowej, należy rozpocząć etapowe budowanie systemu i rozwiązań organizacyjnych pozwalających na skanowanie, gromadzenie i udostępnianie elektronicznych akt sądowych. Już samo zapoczątkowanie procesu digitalizacji akt, rozpoznanie dostępnych rozwiązań czy wypracowanie reguł organizacyjnych pozwalających na gromadzenie i posługiwanie się cyfrowymi aktami - obserwując współczesne trendy - jest niezbędne i konieczne. Należy jednak podkreślić, że docelowo system oparty tylko na skanowaniu akt i rozpoznawaniu tekstu jest niewystarczający. System taki musi pozwolić na zamieszczenie w aktach każdego rodzaju dokumentów cyfrowych i umożliwić zarządzanie nimi.

Podkreślić należy również, że wdrożenie tej praktyki - tak jak wdrożenie większości rozwiązań informatycznych - nie jest możliwe bez posiadania odpowiednich urządzeń i oprogramowania oraz poniesienia kosztów pracy związanych z wdrożeniem i obsługą systemu. Korzyści z wdrożenia dobrej praktyki mogą być rozpatrywane w trzech aspektach: organizacji pracy, pracownika i finansowym. Do korzyści w aspekcie organizacji pracy w zakresie poprawy sprawności postępowania sądowego należy:

- umożliwienie uzyskania szybkiego i łatwego dostępu do akt,

- umożliwienie równoczesnego korzystania z akt przez różne osoby (np. sędziego i pełnomocników stron),

- zminimalizowanie ryzyka utraty, uszkodzenia i modyfikacji akt,

- umożliwienie przechowywania wszystkich akt sprawy w jednym miejscu,

- ułatwienie przekazywania akt do sądu wyższej instancji,

- ułatwienie archiwizacji akt.

Do korzyści w aspekcie pracownika należy:

- ułatwienie dostępu do akt (w szczególności sędziom orzekającym),

- ułatwienie przeszukiwania akt dzięki mechanizmom wyszukiwania tekstu,

- ułatwienie dostępu do innych dokumentów elektronicznych zamieszczonych w aktach (nagrań wideo, dźwięku, zdjęć itp.),

- umożliwienie przypisywania słów kluczowych i znaczników do poszczególnych stron i fragmentów akt,

- umożliwienie zapisywania notatek i komentarzy nanoszonych bezpośrednio przy treści akt.

Do korzyści w aspekcie finansowym należy:

- zmniejszenie kosztów wykorzystania i obsługi akt papierowych, takich jak np.: czasochłonność dostępu do akt, utrudnione przeszukiwanie akt, brak możliwości równoczesnego udostępniania akt różnym osobom, transportowanie akt 
pomiędzy pomieszczeniami sądu, konieczność uzupełniania akt o materiały, które zaginęły lub uległy zniszczeniu,

- zmniejszenie kosztów materiałów biurowych i materiałów eksploatacyjnych drukarek,

- zmniejszenie kosztów zakupu i serwisowania drukarek,

- zmniejszenie przestrzeni potrzebnej na bieżące przechowywanie akt (szafy na akta) $\mathrm{i}$ ich archiwizowanie.

Należy także nadmienić, że posiadanie akt sądowych w postaci cyfrowej w połączeniu z możliwością udostępniania ich przez Internet może być wykorzystane jako udogodnienie dla stron postępowania i ich pełnomocników, którzy będą mogli korzystać z akt bez konieczności osobistego stawiennictwa w sądzie, co przyniesie także oszczędności kosztów związanych z wydrukami, korespondencją i przejazdami.

\section{Charakterystyka dobrej praktyki}

\subsection{Założenia, zakres i funkcje dobrej praktyki}

Dobra praktyka zakłada docelowo stworzenie systemu zarządzania aktami sądowymi w postaci cyfrowej. Wyróżniono w niej pięć poziomów dojrzałości. Na najniższym poziomie zakłada się przeprowadzanie skanowania i rozpoznawania tekstu tylko w przypadku akt, z których korzystanie w procesie orzekania jest szczególnie utrudnione (np. ze względu na ich dużą objętość), lub tych, których digitalizacja powinna szybko przynieść oczekiwane korzyści w postaci skrócenia czasu orzekania. Na poziomach wyższych zakłada się bieżącą digitalizację wszystkich papierowych akt oraz wypracowanie mechanizmów pozyskiwania akt w postaci cyfrowej z różnych, możliwych źródeł, m.in. od prokuratury, stron postępowania, kancelarii prawnych, biegłych. Naturalną konsekwencją posiadania akt w postaci cyfrowej jest także opracowanie sformalizowanego modelu ich szerszego udostępniania i wykorzystania przez uprawnione podmioty (sędziów, osoby w czytelni akt, kancelarie prawne, sądy drugiej instancji itp.). Na najwyższym poziomie zalecana jest optymalizacja sytemu i wdrażanie nowych rozwiązań w zakresie bezpośredniego pozyskiwania akt w postaci cyfrowej.

Na rys. 2 przedstawiono uproszczony diagram przepływu danych wraz z zaznaczonymi funkcjami realizowanymi przez system zarządzania aktami. Na diagramie pokazane są główne wejścia i wyjścia danych. Pozwala on prześledzić drogę akt oraz przedstawia podstawowe funkcje systemu. 


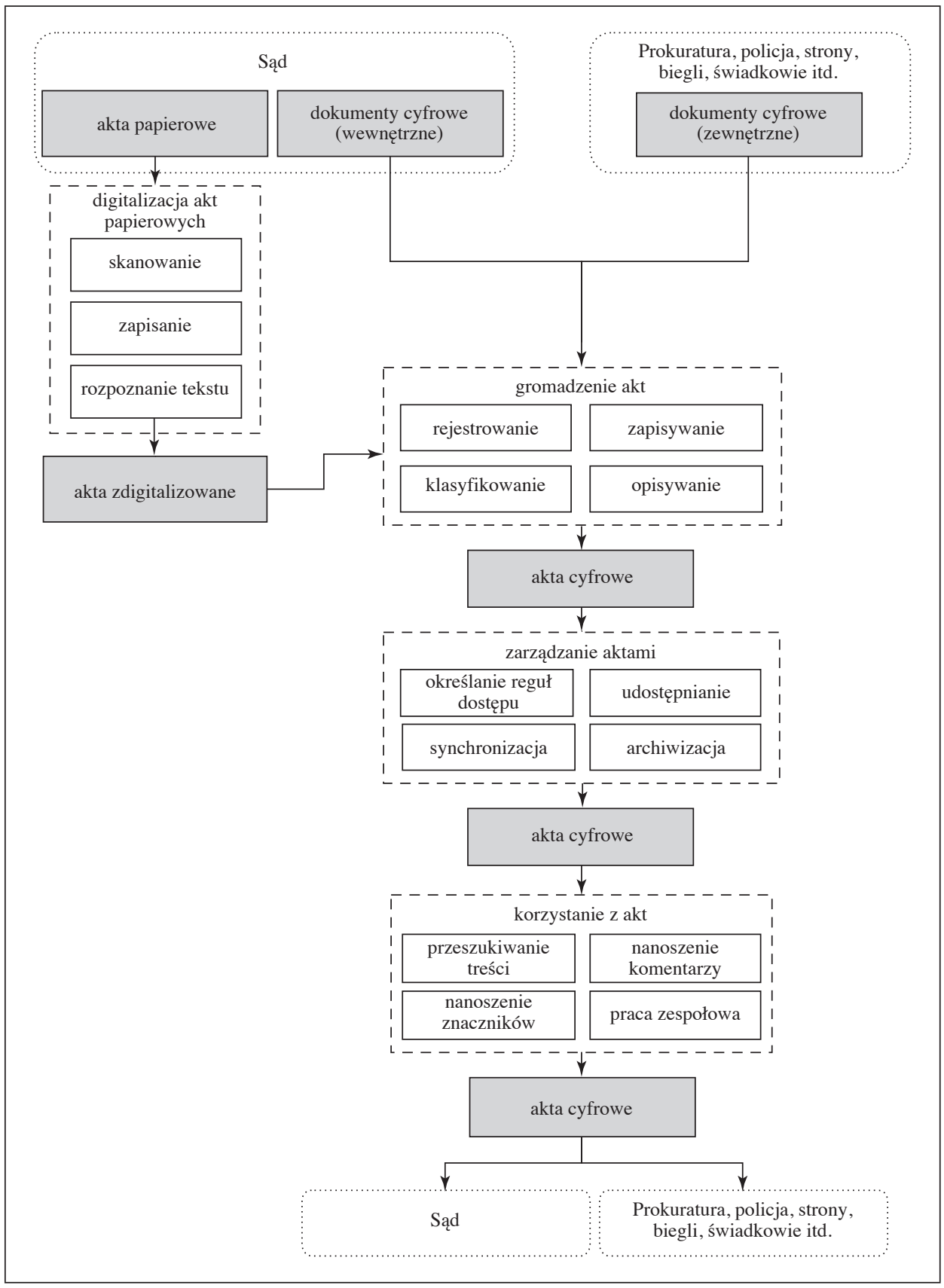

Rys. 2. Diagram przepływu danych w systemie zarządzania aktami cyfrowymi Źródło: opracowanie własne. 


\subsection{Poziomy dojrzałości dobrej praktyki}

Poziom I. Digitalizacja wybranych akt. Na tym poziomie zakłada się digitalizację wybranych akt. Do digitalizacji należy przeznaczyć tylko takie akta, których przetworzenie na postać cyfrową może pomóc w skróceniu czasu zakończenia sprawy, dlatego w większości przypadków będą to akta wielotomowe, których przeszukiwanie i zapoznawanie się ze sprawą jest utrudnione. Oznacza to, że bardzo ważnym elementem jest mechanizm selekcji pozwalający podjąć decyzję o tym, które akta przeznaczone będą do digitalizacji. Pod uwagę powinny być brane m.in. takie czynniki, jak:

- liczba tomów akt,

- charakter sprawy i czas jej trwania,

- umiejętności sędziów orzekających w zakresie korzystania z technologii informatycznych,

- możliwość wykorzystania cyfrowych akt w sądzie wyższej instancji.

Realizacja dobrej praktyki na tym poziomie składać się będzie z następujących etapów:

1) wybranie akt do digitalizacji;

2) digitalizacja akt w postaci papierowej (skanowanie, zapisywanie na dysku, rozpoznawanie tekstu metodą OCR);

3) gromadzenie zdigitalizowanych akt:

- rejestrowanie akt dodanych do systemu,

- zapisywanie plików akt w bazie systemu,

- klasyfikowanie, nadawanie identyfikatorów, sygnatur i opisu akt;

4) uzupełnienie akt o zasoby wewnętrzne w cyfrowej postaci (np. e-protokoły, powiadomienia, nakazy, orzeczenia);

5) zarządzanie aktami w postaci cyfrowej:

- określanie reguł i przydzielanie dostępu użytkownikom wewnętrznym,

- udostępnianie akt bezpośrednio na serwerze,

- udostępnianie akt na komputerach lokalnych użytkowników (kopiowanie akt),

- synchronizowanie akt na serwerze $\mathrm{z}$ aktami zapisanymi lokalnie na komputerach użytkowników,

- tworzenie kopii i archiwizowanie akt;

6) praca użytkowników wewnętrznych z udostępnionymi aktami:

- zaawansowane przeszukiwanie treści akt oraz ich opisów, komentarzy, notatek i słów kluczowych (znaczników),

- nanoszenie opisów, komentarzy i notatek dla poszczególnych fragmentów akt,

- oznaczanie słowami kluczowymi (znacznikami) poszczególnych fragmentów akt,

- wykonywanie pracy zespołowej związanej z aktami. 
Poziom II. Bieżq̨a digitalizacja wszystkich akt. Na tym poziomie dojrzałości zakłada się, że wszystkie akta papierowe będą podlegać procesowi bieżącej digitalizacji. Wykonanie tego zadania będzie w różnym stopniu obciążające dla sądu, głównie w zakresie ponoszonych kosztów osobowych dotyczących pracowników zajmujących się digitalizacją akt. W zamian uzyskuje się uniezależnienie od innych podmiotów, które dostarczają materiały do akt (prokuratura, biegli, strony i ich pełnomocnicy itd.). W przypadku dużego obciążenia sądu, naturalnym rozwinięciem tego etapu jest próba osiągnięcia stanu, w którym jak najwięcej materiałów uzyskiwanych jest bezpośrednio w postaci cyfrowej (poziom III).

Poziom III. Pozyskiwanie w postaci cyfrowej wybranych materiałów do akt. Na tym poziomie jak najwięcej materiałów otrzymywanych z zewnątrz (np. od prokuratury, stron postępowania, biegłych) będzie dostarczanych w postaci cyfrowej. Oznacza to, że konieczne są rozwiązania organizacyjne, dzięki którym możliwe będzie uzyskiwanie jak największej liczby dokumentów cyfrowych. W tym celu niezbędne będą m.in. następujące działania:

- porozumienia między prezesami sądów a prokuraturą i policją, które umożliwią przekazywanie akt w postaci cyfrowej,

- stworzenie możliwości dostarczania przez biegłych, strony i ich pełnomocników pism w postaci elektronicznej (np. przez elektroniczny dziennik podawczy) opatrzonych kwalifikowanym podpisem elektronicznym lub wysłanym z profilu zaufanego ePUAP,

- wyposażenie biur obsługi interesantów w urządzenia pozwalające na bieżące skanowanie składanych dokumentów.

Materiały dostarczone w postaci papierowej w dalszym ciągu podlegać będą bieżącemu skanowaniu.

Etap ten charakteryzuje się przeniesieniem środka ciężkości z procesu digitalizacji dokumentów papierowych na proces pozyskiwania zewnętrznych dokumentów w postaci cyfrowej. Pozyskiwanie to wymaga rozbudowania systemu o mechanizmy pozwalające na przekazywanie cyfrowych materiałów bezpośrednio do SI.

Realizacja tego poziomu składać się będzie z następujących etapów (wyróżnione zostały etapy pozyskiwania zasobów cyfrowych z zewnątrz oraz ich udostępniania na zewnątrz, a niektóre powtarzające się podetapy zostały pominięte):

1) digitalizacja akt w postaci papierowej;

2) gromadzenie akt zdigitalizowanych w systemie;

3) uzupełnienie akt:

- o zasoby wewnętrzne w postaci cyfrowej (np. e-protokoły, powiadomienia, nakazy, orzeczenia),

- o zasoby zewnętrzne w postaci cyfrowej (np. akta prokuratury, opinie biegłych, pisma procesowe składane przez strony); 
4) zarządzanie aktami w postaci cyfrowej np.:

- określanie reguł i przydzielanie dostępu użytkownikom wewnętrznym,

- określanie reguł i przydzielanie dostępu użytkownikom zewnętrznym;

5) praca użytkowników wewnętrznych związana z udostępnionymi aktami;

6) praca użytkowników zewnętrznych związana z udostępnionymi aktami przeszukiwanie treści akt.

Poziom IV. Pozyskiwanie w postaci cyfrowej wszystkich materiałów do akt. Jedyna różnica funkcjonalna pomiędzy poziomem IV a poziomem III polega na tym, że wszystkie materiały do akt dostarczane z zewnątrz będą wyłącznie w postaci cyfrowej. Tym samym wyeliminowana zostanie konieczność skanowania akt papierowych.

Poziom V. Optymalizacja systemu zarzq̨dzania aktami. Na tym poziomie wszystkie działania polegać będą na utrzymywaniu systemu i wprowadzaniu zmian udoskonalających - w miarę pojawiania się nowych możliwości w zakresie pozyskiwania, przechowywania, udostępniania, katalogowania, archiwizowania akt cyfrowych. Poziom ten zakłada opracowanie sformalizowanego modelu gromadzenia cyfrowych akt, zarządzania nimi i udostępniania ich zarówno wewnątrz, jak i na zewnątrz. Opracowanie takiego modelu pozwoli na opisanie i zoptymalizowanie wszystkich zachodzących w nim procesów. Konieczne będzie także śledzenie trendów i wdrażanie nowych rozwiązań w tym zakresie.

\subsection{Koszty wdrożenia dobrej praktyki}

Do wdrożenia dobrej praktyki konieczne jest:

- posiadanie skanera - zakup lub przeznaczenie posiadanego już urządzenia, jeżeli spełnia ono odpowiednie wymogi techniczne,

- posiadanie systemu informatycznego klasy DMS pozwalającego na skanowanie, gromadzenie akt w postaci cyfrowej, zarządzanie nimi i ich udostępnianie,

- przeszkolenie i oddelegowanie pracownika do wykonywania czynności skanowania i obsługi systemu,

- przeszkolenie pracowników w zakresie korzystania z systemu.

Koszty wdrożenia dobrej praktyki obejmują zatem:

- koszt zakupu skanera i oprogramowania przetwarzającego zeskanowane akta do postaci cyfrowej (w tym narzędzia OCR),

- koszt systemu informatycznego do zarządzania aktami,

- koszt pracy wynikający ze skanowania akt i obsługi systemu,

- koszt szkolenia pracowników korzystających z systemu.

Szkolenia pracowników korzystających z systemu będą dokonywane przez personel informatyczny. Obsługa tego typu systemów przez użytkowników jest prosta, dlatego szkolenia te nie będą wymagały dużych nakładów czasu. 
Jeżeli chodzi o koszty pracy poniesione przy skanowaniu akt, to należy zaznaczyć, że relacja pomiędzy nimi a wydajnością skanera jest wyraźna - im większy będzie koszt poniesiony na zakup skanera (skaner umożliwiający szybkie skanowanie, wyposażony w podajnik, moduł skanowania dwustronnego itd.), tym mniejsze będą koszty osobowe przeznaczone na obsługę samego procesu skanowania. Na rynku dostępne są tzw. skanery dokumentowe. Profesjonalny skaner dokumentowy średniej klasy pozwala na skanowanie dokumentów w formacie A4 lub A3, z prędkością 60 kartek/minutę, wyposażony jest w podajnik kartek (ADF), system wykrywania równoczesnego wciągnięcia kilku kartek papieru, a jego obciążenie dzienne wynosi ok. 10 tys. kartek. Ceny urządzeń w tej klasie wynoszą ok. 15 tys. zł. Należy zaznaczyć, że są także dostępne urządzenia umożliwiające skanowanie z prędkością 200 kartek na minutę (dwustronnie) i bez limitu dziennego, jednak ceny takich urządzeń są nawet kilkukrotnie wyższe.

Możliwości uzyskania oprogramowania do zarządzania aktami sądowymi są różne, można w tym celu wykorzystać oprogramowanie:

- komercyjne, np. Microsoft SharePoint, Xerox DocuShare,

- komercyjne napisane na zamówienie przez firmę zewnętrzną,

- dostarczane wraz z zakupionym skanerem (niektóre modele wyposażone są w oprogramowanie typu DMS),

- otwarte (ogólnodostępne i darmowe), np. Open Knowledge Management (OpenKM), KRYSTAL ${ }^{\text {TM }}$ DMS,

- stworzone w celu wykorzystania w polskim sądownictwie, np. system InWAS (wykorzystywany m.in. przez Sąd Rejonowy w Białymstoku i Sąd Rejonowy Katowice-Zachód),

- stworzone samodzielnie przez informatyków sądu,

- stworzone samodzielnie przez informatyków sądu, będące modyfikacją oprogramowania otwartego.

W zależności od wielu czynników (m.in. rodzaju wybranego oprogramowania, liczby potrzebnych licencji, możliwości i umiejętności sądowego oddziału informatyki, posiadanego już oprogramowania) koszt oprogramowania (jego zakupu, opracowania lub dostosowania) może kształtować się różnie - od poniesienia wyłącznie kosztów osobowych (praca informatyków sądu) do nawet kilkudziesięciu tysięcy złotych wydanych na zakup oprogramowania komercyjnego. Rozpoznanie możliwości danego sądu musi być przeprowadzone na etapie wdrażania praktyki. Niemniej jednak zalecane jest, aby sądy, które zdecydowały się na wybór tej praktyki, wspólnie podjęły się stworzenia potrzebnego oprogramowania (np. przez wyłoniony z różnych sądów zespół informatyków) lub razem negocjowały cenę oprogramowania komercyjnego. 


\section{Wnioski z wdrożenia dobrej praktyki}

Dobra praktyka „Zarządzanie aktami sądowymi w postaci cyfrowej” została wdrożona $\mathrm{w} 7 \mathrm{sądach} \mathrm{( \textrm {w }} 6 \mathrm{w}$ ramach pilotażu podstawowego i $\mathrm{w} 1 \mathrm{w}$ ramach pilotażu uzupełniającego). W ramach pilotażu podstawowego były to: Sąd Okręgowy w Białymstoku, Sąd Okręgowy w Rzeszowie, Sąd Rejonowy w Rzeszowie, Sąd Okręgowy w Katowicach, Sąd Rejonowy SR Katowice-Zachód w Katowicach, Sąd Okręgowy Warszawa-Praga w Warszawie.

Harmonogram wdrażania oraz omówienie poziomu zaawansowania prac w poszczególnych sądach pilotażowych zamieszczono w opracowaniu (Raport całościowy... 2014).

Pomimo początkowo dużego zainteresowania sądów ostatecznie zainteresowanie tą praktyką spośród zaproponowanych praktyk informatycznych okazało się najmniejsze. Za podstawową przyczynę należy uznać brak środków finansowych na zakup urządzeń i oprogramowania (Badanie ewaluacyjne... 2015). Sądy, które zdecydowały się na jej wdrożenie, dysponowały już elementami systemu zarządzania dokumentami lub miały wdrożone pewne procedury skanowania akt sądowych. Wykorzystały one wdrożenie dobrej praktyki jako okazję do analizy swoich rozwiązań i rozbudowy posiadanego zaplecza sprzętowego i programowego.

Na podstawie przeprowadzonych wywiadów z pracownikami sądów (metodą ITI i CAWI) oraz informacji uzyskanych w ramach współpracy autora z firmą wdrażającą, można wskazać najważniejsze zalety i ograniczenia dobrej praktyki.

Do głównych jej zalet należy:

- przeprowadzenie analizy obiegu akt sądowych,

- ustalenie rozwiązania lub narzędzia informatycznego do zarządzania aktami w postaci cyfrowej,

- opracowanie procedury do skanowania akt i ich obsługi w formie elektronicznej.

Do jej ograniczeń i trudności podczas wdrażania dobrej praktyki zaliczono:

- konieczność zakupu urządzeń i oprogramowania niezbędnego do realizacji praktyki,

- konieczność przeprowadzenia szkoleń pracowników związanych z przetwarzaniem dokumentów do postaci cyfrowej oraz ich udostępnianiem.

Należy podkreślić, że pomimo niewielkiej liczby wdrożeń tej praktyki w sądach panowało przeświadczenie o jej dużej przydatności. Potrzeba wyeliminowania niedogodności związanych z obsługą akt papierowych była zauważalna. Należy więc przypuszczać, że w przyszłości wraz z rosnącą dostępnością systemów DMS i coraz większą liczbą dokumentów w postaci cyfrowej tego typu rozwiązania zostaną powszechnie wprowadzone do polskiego wymiaru sprawiedliwości. 
Należy także dodać, że opracowywanie koncepcji dobrych praktyk dla środowiska sądowego było ciekawym doświadczeniem, które pozwoliło na wdrażanie rozwiązań informatycznych w specyficznych, sformalizowanych warunkach. Obecnie zespół przygotowuje badania poświęcone ocenie efektów wdrożenia dobrych praktyk informatycznych w sądach powszechnych.

\section{Literatura}

Azad A. (2008), Implementing Electronic Document and Record Management Systems, Auerbach Publications, New York.

Badanie ewaluacyjne pilotażu wdrażania dobrego zarzqdzania jednostkami wymiaru sprawiedliwości w ramach projektu „PWP Edukacja w dziedzinie zarzqdzania czasem i kosztami postępowań sq̨dowych - case management”. Raport końcowy (2015), ASM - Centrum Badań i Analiz Rynku, Kutno.

Baskerville R.L. (1999), Investigating Information Systems with Action Research, Communications of the Association for Information Systems, vol. 2, Article 19, http://aisel. aisnet.org/cais/vol2/iss1/19 (data dostępu: 15.09.2014).

Baskerville R.L., Wood-Harper A.T. (1996), A Critical Perspective on Action Research as a Method for Information Systems Research, ,Journal of Information Technology”, vol. 11, nr 3, https://doi.org/10.1080/026839696345289.

The Best Document Management Software of 2018 (2018), https://www.pcmag.com/ article2/0,2817,2490969,00.asp (data dostępu: 15.06.2018).

COBIT 4.1. Metodyka. Cele kontrolne. Wytyczne zarzqdzenia. Modele dojrzałości (2010), IT Governance Institute, Stowarzyszenie Audytu, Bezpieczeństwa i Kontroli Systemów Informacyjnych ISACA, Warszawa.

Cole M., Avison D. (2007), The Potential of Hermeneutics in Information Systems Research, „European Journal of Information Systems”, vol. 16, nr 6, https://doi.org/10.1057/ palgrave.ejis.3000725.

Davison R.M., Martinsons M.G., Ou C.X.J. (2012), The Roles of Theory in Canonical Action Research, „MIS Quarterly”, vol. 36, nr 3, https://doi.org/10.2307/41703480.

Document Management Software Review (2016), http://document-management-softwarereview.toptenreviews.com/ (data dostępu: 22.12.2016).

Grabowski M., Madej J., Trąbka J. (2018), Koncepcja metodyki projektowania i wdrażania dobrych praktyk informatycznych dla sqdów powszechnych, „Zeszyty Naukowe Uniwersytetu Ekonomicznego w Krakowie", nr 4(976), https://doi.org/10.15678/ ZNUEK.2018.0976.0413.

Green W.G. (1993), Introduction to Electronic Document Management Systems, Academic Press, Cambridge Mass., USA.

Informatyzacja postępowania cywilnego. Teoria i praktyka (2016), red. K. Flaga-Gieruszyńska, J. Gołaczyński, D. Szostek, Seria Monografie Prawnicze, C.H. Beck, Warszawa.

Keathley E. (2014), Digital Asset Management: Content Architectures, Project Management, and Creating Order out of Media Chaos, Apress, New York.

Laudon K.C., Laudon J.P. (2016), Management Information Systems: Managing the Digital Firm, Pearson Hall, Harlow. 
Modernizacja procesów zarzqdzania kadrami wymiaru sprawiedliwości. Dobre praktyki (2011), Ministerstwo Sprawiedliwości, Warszawa.

Paulk M.C., Weber C.V., Curtis B., Chrissis M.B. (1993), Capability Maturity Model for Software (Version 1.1), Technical Report CMU/SEI-93-TR-024 ESC-TR-93-177, February, Software Engineering Institute, Carnegie Mellon University, Pittsburgh, PA, https://resources.sei.cmu.edu/asset_files/TechnicalReport/1993_005_001_16211.pdf (data dostępu: 13.04.2018).

Program zintegrowanej informatyzacji państwa (2013), Ministerstwo Administracji i Cyfryzacji, Warszawa.

Raport całościowy z wdrożenia za okres od 1 grudnia 2013 r. do 24 października 2014 r. (2014), oprac. WYG International, WYG Consulting, WYG PSDB, Uniwersytet Ekonomiczny w Krakowie, Instytut Allerhanda na zlecenie Krajowej Szkoły Sądownictwa i Prokuratury, http://www.efs2007-2013.gov.pl/Dokumenty (data dostępu: grudzień 2016).

Stajda E. (2013), Document Management with SAP DMS, SAP Press.

Sutton M.J.D. (1996), Document Management for the Enterprise: Principles, Techniques, and Applications, Wiley \& Sons.

Wachnik B. (2016), Wdrażanie systemów informatycznych wspomagajq̨cych zarzqdzanie, PWE, Warszawa.

\section{Managing Digital Court Records - Good Practice}

(Abstract)

The paper presents good practice in IT and the use of DMS (Document Management System) for digital court records. The concept of good practice was formulated during the implementation of the project "Education in the area of time management and cost management of judicial proceedings - case management" (a part of the Human Capital Programme). This project was one of the components supporting the reform of the Polish judiciary and sought to increase the efficiency of the judicial system by lowering costs and increasing the skills of those employed in the judiciary. The article describes the use of digital acts in the courts and the conditions and background of this practice (available systems, means of implementation), the purpose and benefits of its implementation, and the basic assumptions, scope and functions that should be implemented at different maturity levels, costs and the conclusions of the implementation of good practice.

Keywords: document management system, information system, IT good practices, judiciary, courts, efficiency of judicial system. 